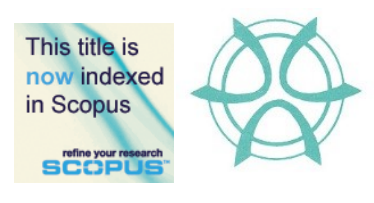

\title{
THE DEVELOPMENT OF PENANG SHOP PRICE INDEX (PSPI) USING LASPEYRES HEDONIC PRICE MODEL
}

\author{
Mohamad Hafiz Jamaludin $^{1}$, Suriatini Ismail ${ }^{2}$, Norziha Ismail ${ }^{3}$ \\ ${ }^{1}$ Faculty of Creative Technology and Heritage, \\ UNIVERSITI MALAYSIA KELANTAN, MALAYSIA \\ ${ }^{2}$ Faculty of Architecture and Ekistics, \\ UNIVERSITI MALAYSIA KELANTAN, MALAYSIA \\ ${ }^{3}$ Valuation and Property Services Department \\ MINISTRY OF FINANCE
}

\begin{abstract}
The index is considered an important benchmark and is a decision-making tool in the financial and capital markets, as well as in the property market. In Malaysia, continuous monitoring of property price movements is important as almost half of banking exposure is on property. Further, NAPIC has published indicators displaying the performance of property such as MHPI and PBO-RI. However, indicators regarding the price of commercial property are still less widely published in Malaysia. This study was conducted to develop indicators related to the price of commercial property, especially to shop property. This study has focused on the state of Penang as a study area. The literature review methodology is used to identify existing methods and practices used in developing the index of commercial property both in Malaysia and internationally. In determining the appropriate form of hedonic functions for the development of PSPI, analysis of dependent and independent variables was performed. Meanwhile, the development of the index is based on the Laspeyres hedonic model which is the same as the development of MHPI and PBO-RI. The development of PSPI will be able to help the industry and investors to make decisions and benchmark the performance of shop. This is also one of the pilot studies in Malaysia to form an indicator of commercial property.
\end{abstract}

Keyword: Property Indicator, Shop Property, Penang, Laspeyres, PSPI, Investor

\footnotetext{
${ }^{1}$ Corresponding Author. Email: mdhafiz@jpph.gov.my
} 


\section{INTRODUCTION}

Index are considered important benchmarks and are decision-making tools in the financial and capital markets, as well as in the property market (Farragher et al, 2008). In economic maturity, its importance has led to the development of internationally renowned indexes especially in the United States such as the National Council of Real Estate Investment Fiduciaries (NCREIF) Property Index (NPI), Moody's / REAL Commercial Property Index, Massachusetts Institute of Technology and Centre for Real Estate (MIT-CRE) TransactionBased Index. Apart from the United States, there is also an index published by Investment Property Databank (IPD) in the United Kingdom known as the IPD Index. This index shows the performance of commercial and industrial properties which are owned by investment institutions and property companies. Indexes can also help investors in managing, formulating strategies, and making decisions for their investment portfolios.

In Malaysia, the Malaysian House Price Index (MHPI) was first developed in 1997. MHPI is develop using the Laspeyres Hedonic Price Model, where the index is calculated by using the Laspeyres weighted formula (NAPIC, 2018). MHPI is considered one of the important macroeconomic indicators for Bank Negara Malaysia (BNM) and the Ministry of Finance Malaysia (MOF) (BNM, 2017). Following on the introduction of MHPI, NAPIC has published another index known as the Purpose-built Office Rental Index (PBO-RI) Wilayah Persekutuan Kuala Lumpur. The index was first published in 2011 with quarterly publications and uses the Laspeyres Hedonic Price Model. PBO-RI is a commercial property rental indicator focusing on Purpose-built Office in the Federal Territory of Kuala Lumpur. Starting in 2016, this index has been expanded to 3 states namely Selangor, Johor, and Penang known as the PBO-RI Klang Valley (WPKL and Selangor), Johor Bahru, and George Town.

Overall, PBORI is the only index published by NAPIC that shows the performance of commercial property in Malaysia, but it is related on rental. There is also a study conducted by Aina Edayu (2015) on the development of office price index in the Kuala Lumpur, but it is involves of office price. Thus, this study is a pioneer in the development of a commercial property index that specializes in shop property.

\section{LITERATURE REVIEW}

There are two methodologies used in the development of property indices related to commercial property there are appraisal and transaction method. NPI is a commercial property index developed using an appraisal method. NPI has been a key benchmark for measuring property performance to investment institutions since its introduction in 1978 (Fisher, 2003). According to Fisher (2003) and Chegut et al. (2013), Junainah et al. (2019) and Tuti Haryati (2018), the lack of 
Mohamad Hafiz Jamaludin, Suriatini Ismail, Norziha Ismail

The Development of Penang Shop Price Index (Pspi) Using Laspeyres Hedonic Price Model

data record and the less of sales data at that time have led to the development of the index using this approach. However, this approach is not sensitive to current property market and having problem in the valuing processs that is lack of property transaction (Geltner et al., 2003 \& Chau et al., 2005).

The development of property indices using a transaction method has long been used over the past decade by using evidence of transaction (Bailey et al., 1963; Rosen, 1974; Quigley, 1995; Francke, 2010). This method can be separate into three there are the Repeat Sales Model, Hedonic Price Model, and Hybrid Model. The Repeat Sales model was developed by Bailey et al. (1963), in which the transaction of the same property is studied in two or more periods. Bailey et al. (1963) and Case and Shiller (1987) are pioneers who use the Repeat Sales method in developing index in the residential sector because of the frequent transaction. However, its use in the development of commercial property index is less suitable because it is difficult to obtain commercial property transaction in a short period. Commercial property prices are more volatile which results in them being less transferable than residential property (Hasliza et al., 2018). Yet in Florida, USA a study by Gatzlaff and Haurin (1998) found that indices developed using this model is more realistic than NCREIF indices developed using the appraisal basis.

The hedonic price model is one of the methods developed using the transaction method and has been used more than 70 years ago (Aina Edayu, 2015). This model is developed by considering the characteristics of a property and there is no need for repeat sales model (Haurin, 2003). In principle, this technique can be implemented if all the characteristics that affect the value of the property can be obtained to control the differences in quality of the characteristics of the property transferred at a time (Fisher et al., 2007). The implementation of this method is more relevant if the quality of all hedonic variables is obtainable and complete information is available. The hedonic model has a strong theoretical basis (Griliches 1971; Rosen 1974) because it uses regression techniques to control changes in composition and quality. The use of hedonic price models has been used in the development of MHPI and PBO-RI which have become important benchmarks in Malaysia.

Another model in developing index using transaction-based method is hybrid. The hybrid model essentially combines the repeat sales model and the hedonic price model developed by Quigley (1995). Even so, Quigley (1995) did not see any advantage in developing an index using a hybrid model over a hedonic price model. Tables 1 and 2 show the indexes related to property internationally and in Malaysia along with the methods used in its development. 
PLANNING MALAYSIA

Journal of the Malaysia Institute of Planners (2021)

Table 1: Summary of International Commercial Property Index and Methodology's

\begin{tabular}{|c|c|c|c|}
\hline No. & Index & Description & Methodology \\
\hline 1. & $\begin{array}{l}\text { NCREIF (National } \\
\text { Council of Real Estate } \\
\text { Investment } \\
\text { Fiduciaries) Property } \\
\text { Index Returns (NPI) }\end{array}$ & $\begin{array}{l}\text { Measuring the property } \\
\text { performance through income } \\
\text { earned from property. }\end{array}$ & Appraisal \\
\hline 2. & IPD Market Indices & $\begin{array}{l}\text { This index measures the rate of } \\
\text { return on property and allows } \\
\text { comparisons between major } \\
\text { asset classes. }\end{array}$ & Appraisal \\
\hline 3. & $\begin{array}{lr}\begin{array}{l}\text { NCREIF } \\
\text { (Transaction }\end{array} & \text { TBI } \\
\text { Index) } & \text { Based } \\
\end{array}$ & $\begin{array}{l}\text { Complementary index to shares } \\
\text { of NPI Index and bonds based } \\
\text { on transaction. }\end{array}$ & $\begin{array}{l}\text { Transaction } \quad \& \\
\text { Appraisal }\end{array}$ \\
\hline 4. & Moodys/REAL CPPI & $\begin{array}{l}\text { Measuring changes in the price } \\
\text { of commercial property for } \\
\text { markets in the United States and } \\
\text { the United Kingdom }\end{array}$ & $\begin{array}{ll}\text { - } & \text { Transaction } \\
\text { - } & \text { Repeat Sales } \\
& \text { Model }\end{array}$ \\
\hline 5. & $\begin{array}{l}\text { MIT-CRE TBI } \\
\text { *started from Q2 2011, } \\
\text { TBI produce and } \\
\text { publish by NCREIF. }\end{array}$ & $\begin{array}{l}\text { This index measures market } \\
\text { movements and return on } \\
\text { investment based on the transfer } \\
\text { price of property sold in the } \\
\text { NCREIF Index database. }\end{array}$ & $\begin{array}{ll}- & \text { Transaction } \\
- & \text { Hedonic } \\
& \text { Model }\end{array}$ \\
\hline 6. & $\begin{array}{l}\text { S\&P/GRA } \\
\text { Commercial } \\
\text { Estate Indices }\end{array}$ & $\begin{array}{l}\text { This index is a reliable and } \\
\text { consistent benchmark for } \\
\text { commercial property prices in } \\
\text { the United States. }\end{array}$ & Transaction \\
\hline 7. & 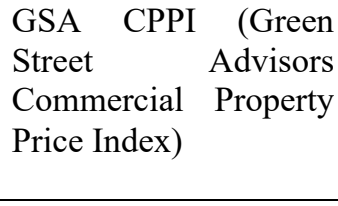 & $\begin{array}{l}\text { This index measures the } \\
\text { performance of the REIT } \\
\text { portfolio which comprises a } \\
\text { large part of the REIT } \\
\text { capitalization sector. }\end{array}$ & Transaction \\
\hline 8. & $\begin{array}{l}\text { S\&P } \quad \text { Australian } \\
\text { Indices (S\&P/ASX) }\end{array}$ & $\begin{array}{l}\text { Major equity index invested in } \\
\text { Australia. }\end{array}$ & $\begin{array}{l}\text { The index is } \\
\text { calculated based } \\
\text { on a weighted } \\
\text { aggregate } \\
\text { methodology. }\end{array}$ \\
\hline 9. & $\begin{array}{lr}\text { EDHEC } & \text { IEIF } \\
\text { Commercial } & \text { Property } \\
\text { Price Index (France) }\end{array}$ & $\begin{array}{l}\text { An index that measures the } \\
\text { performance of unlisted } \\
\text { property is a collective } \\
\text { investment company investing } \\
\text { in commercial property in } \\
\text { France. }\end{array}$ & Transaction \\
\hline
\end{tabular}

Source: Literature Review 
Mohamad Hafiz Jamaludin, Suriatini Ismail, Norziha Ismail

The Development of Penang Shop Price Index (Pspi) Using Laspeyres Hedonic Price Model

Table 2: Summary Property Index in Malaysia and Methodology's

\begin{tabular}{|c|c|c|c|}
\hline No. & Index & Description & Methodology \\
\hline 1. & MHPI by NAPIC & $\begin{array}{l}\text { - Measure the performance } \\
\text { and price movement of } \\
\text { residential property in } \\
\text { Malaysia }\end{array}$ & $\begin{array}{ll}\text { - } & \text { Transaction } \\
\text { - } & \text { Weighted } \\
\text { Regression } \\
\text { Laspeyres } \\
\text { Model }\end{array}$ \\
\hline 2. & $\begin{array}{lr}\text { Residential Property } \\
\text { Index (RPI) by } \\
\text { Malaysian Institute of } \\
\text { Economic Research } \\
\text { (MIER) }\end{array}$ & $\begin{array}{l}\text { - It is designed to complement } \\
\text { macro surveys, namely } \\
\text { business situation studies } \\
\text { and consumer sentiment } \\
\text { studies. }\end{array}$ & - $\quad$ Surveys \\
\hline 3. & $\begin{array}{l}\text { Indeks Harta Tanah by } \\
\text { Bursa Malaysia }\end{array}$ & $\begin{array}{l}\text { - Measure the performance of } \\
\text { the property company under } \\
\text { it. }\end{array}$ & $\begin{array}{l}\text { - } \begin{array}{l}\text { Based on } \\
\text { company } \\
\text { performance }\end{array} \\
\end{array}$ \\
\hline 4. & $\begin{array}{l}\text { PBO-RI Klang Valley, } \\
\text { Johor Bahru \& George } \\
\text { Town }\end{array}$ & $\begin{array}{l}\text { - Measure the performance } \\
\text { and movement of office } \\
\text { rental prices in the Klang } \\
\text { Valley, Johor Bahru \& } \\
\text { George Town. }\end{array}$ & $\begin{array}{ll} & \text { Transaction } \\
\text { (Rental) } \\
\text { - } \\
\text { Laspeyres } \\
\text { Hedonic } \\
\text { Model }\end{array}$ \\
\hline 5. & $\begin{array}{l}\text { KL-OPI by Aina } \\
\text { Edayu }(2015)\end{array}$ & $\begin{array}{l}\text { - Measure the performance } \\
\text { and price movement of } \\
\text { office property in Kuala } \\
\text { Lumpur. }\end{array}$ & $\begin{array}{ll}- & \text { Transaction } \\
\text { - Conventional, } \\
\text { Laspeyres \& } \\
\text { Chained } \\
\text { Regression } \\
\text { Model } \\
\end{array}$ \\
\hline 6. & $\begin{array}{l}\text { Penang Pre-war Shop } \\
\text { Price Index by Henry } \\
\text { Butcher }\end{array}$ & $\begin{array}{l}\text { - Measure the performance } \\
\text { and price movement of pre- } \\
\text { war shop in Penang does not } \\
\text { index. }\end{array}$ & - $\quad$ Transaction \\
\hline
\end{tabular}

Refer to Tables $1 \& 2$, the index development by using the transaction method is frequently used. Besides, the development of MHPI and PBO-RI also uses the Laspeyres Hedonic Price Model. Therefore, this study has considered developing PSPI using the transaction method with Laspeyres Hedonic Price Model is appropriate based on current practices in Malaysia for property index development.

\section{SHOP PROPERTY MARKET IN PENANG}

In 2014, Penang existing stock for shops are 30,200 units which represents 7.5\% of the total existing supply for shop in Malaysia. This supply is the fourth highest behind the big states in Malaysia there are Selangor, Johor, and Perak. 


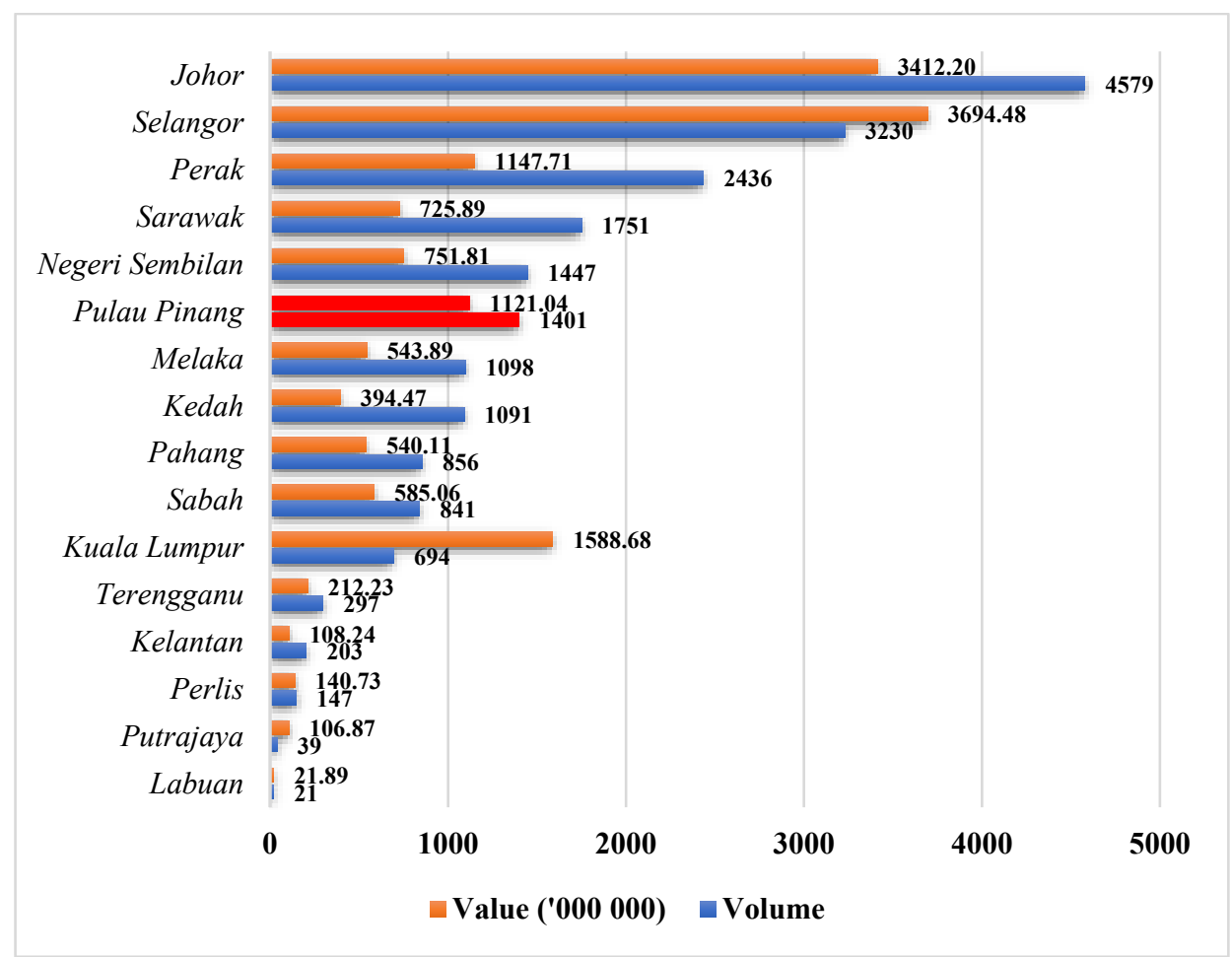

Figure 1: Volume and Value of Shop Property Transaction by State in 2014 Source: Property Market Report 2014, NAPIC

In terms of transaction volume, Penang is the sixth highest state that recorded the transaction of shop with a record of 1,401 units as shown in Figure 1 above. It represents $7.0 \%$ of the total shop transactions in 2014. However, in terms of transaction value, Penang is ranked fifth with value of RM1,121.04 million representing $7.4 \%$ of the total value transaction for shop property in Malaysia. From this data shows that Penang is one of the active states in property market. Therefore, the selection of the state of Penang as a study area is appropriate and suitable to develop an index for shop property.

\section{FINDINGS}

\section{Data Description}

Initially, total of 14,675 (year 2005 to 2008) shop transaction data were used for this study. This data that can be categorized into 3 there are physical, location, and transaction information. Table 3 shows the description of the variables. 
Mohamad Hafiz Jamaludin, Suriatini Ismail, Norziha Ismail

The Development of Penang Shop Price Index (Pspi) Using Laspeyres Hedonic Price Model

Table 3: Variables Description

\begin{tabular}{|c|c|c|c|}
\hline \multicolumn{2}{|c|}{ Variable } & Description & Measurement \\
\hline \multirow{4}{*}{ 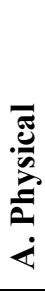 } & $\begin{array}{l}\text { 1. Number of } \\
\text { levels }\end{array}$ & Shows the number of shop floors & $\begin{array}{l}\text { Ratio - measures } \\
\text { in number }\end{array}$ \\
\hline & 2. Land Area & Land area size & $\begin{array}{l}\text { Ratio - measures } \\
\text { in square metre }\end{array}$ \\
\hline & 3. Building Area & Building area size & $\begin{array}{l}\text { Ratio - measures } \\
\text { in square metre }\end{array}$ \\
\hline & 4. Building Age & Shows current age of shop & Ratio - year \\
\hline صِ & $\begin{array}{l}\text { 1. Area } \\
\text { Classification }\end{array}$ & $\begin{array}{l}\text { Describe the location of the property as } \\
\text { follows: } \\
\text { i. Main City Centre } \\
\text { ii. Main Rural } \\
\text { iii. Secondary City Centre } \\
\text { iv. Secondary Rural } \\
\text { Inland }\end{array}$ & Nominal \\
\hline \multirow{7}{*}{ ن } & 1. Tenure & $\begin{array}{ll}\text { i. } & \text { Freehold } \\
\text { ii. } & \text { Lease Hold } 99 \text { year } \\
\text { iii. } & \text { Leasehold } 60 \text { year } \\
\end{array}$ & Nominal \\
\hline & $\begin{array}{l}\text { 2. Date of } \\
\text { Transaction }\end{array}$ & Date of sale and purchase agreement & $\begin{array}{l}\text { Ratio - measure } \\
\text { based on day/ } \\
\text { month/ year }\end{array}$ \\
\hline & $\begin{array}{l}\text { 3. Transaction } \\
\text { Share }\end{array}$ & Shows share of transaction & $\begin{array}{l}\text { Ratio - measure in } \\
\text { number }\end{array}$ \\
\hline & 4. First Transfer & $\begin{array}{l}\text { Indicates whether the property was } \\
\text { transferred for the first time or not. }\end{array}$ & Nominal \\
\hline & 5. Buyer Status & Buyer citizenship status & Nominal \\
\hline & 6. Seller Status & Seller citizenship status & Nominal \\
\hline & $\begin{array}{l}7 . \quad \text { Declared } \\
\text { Price }\end{array}$ & $\begin{array}{l}\text { The price is agreed between the buyer } \\
\text { and the seller and is included in the sale } \\
\text { and purchase agreement. }\end{array}$ & $\begin{array}{l}\text { Ratio - measure in } \\
\text { Ringgit Malaysia }\end{array}$ \\
\hline
\end{tabular}

From 14,675 data, only 6,520 data used for PSPI development with the year involved from 2008 to 2014 . This is due to problems in data descriptions such as lack of information, incomplete information, selection of area samples, and so on. This removal needs to be done to ensure index developed is more accurate and comprehensive.

\section{Developing Index Using Laspeyres Hedonic Price Model}

In Malaysia, the Hedonic Price Model with the Laspeyres Technique is most widely used in the development of the property price index. It is in developing MHPI and PBORI that published by NAPIC. Besides, Aina Edayu (2015) also 
applies this technique in the development of office price index, namely KL-OPI. The Laspeyres Hedonic Model only uses model of the independent variable and ignores the time assumption variables. This technique allows estimates of different parameters to be estimated each year and requires a separate model for each year. The formula for this model is as follows:

$\ln P=\beta_{0}+\beta_{1} X_{1}+\ldots \ldots \ldots . .+\beta_{n} X_{n}$

Where;

$\ln P$

represents declared price of the shop property in log form. Converting a dependent variable in $\log$ form makes this equation a semi log. Conversion of dependent variables to log values is intended to obtain data normality;

$X_{1} \ldots X_{n} \quad \ldots \ldots \ldots$ represent vectors $\mathrm{n}$ independent variables as described in Table 3;

$\beta$

represents an estimated parameter vector;

The parameter estimates are obtained by estimating separate regressions for each year. At the same time, it is also necessary to determine the weights for the base year i.e. the average of the quantitative variables considered in the model formation and the percentage of qualitative variables. According to Fisher et al (2007), the advantage of this technique is that the quantity of data can only be seen from the base year. This gives a better comparison and accurate over time. Thus, changes in the index can be related to price changes.

For the Laspeyres technique, the time assumption variables are not included in the equation and the data are regressed according to each year. The index generated from this technique also known as fix weighted or base weighted. The base year is 2008. The formula for calculating the Laspeyres index is as follows:

$P I_{t}=100\left(\begin{array}{c}e^{\beta_{t} X_{0}} \\ e^{\beta_{0} X_{0}}\end{array}\right)$

Where:

$P_{t} \quad \ldots \ldots \ldots . \quad$ represents the price index for a particular year;

$\beta_{0} \quad \ldots \ldots \ldots . . \quad$ represents the regression coefficient of the hedonic model of the base year set i.e. 2008;

$\beta_{t} \quad \ldots \ldots \ldots$ represents the regression coefficient of the current hedonic model;

$\mathrm{X}_{0} \quad \ldots \ldots \ldots$ represents the average variable of shops sold in the base year 2008 . 
Mohamad Hafiz Jamaludin, Suriatini Ismail, Norziha Ismail

The Development of Penang Shop Price Index (Pspi) Using Laspeyres Hedonic Price Model

The use of the Laspeyres Hedonic Price Model Technique in the development of PSPI is similar to the development of the MHPI and PBO-RI. The different between this index is in terms of base year, where the latest base year for MHPI and PBO-RI is 2010 while PSPI is 2008. There are no significant implications, it will only create 2 different base year.

Table 4 below shows the index generated from the Laspeyres Hedonic Price Model, while Figure 2 shows the index change rate from 2008 to 2014. The regression results for each year showing the Adjusted R Square between 52.2\% to $67.5 \%$. Overall, it is found that the index trend generated using Laspeyres method shows an upward pattern. The highest change index rate was recorded in 2012 , an increase of $20.3 \%$ with an index point of 165.0. A similar growth was also recorded in 2011 which was $20.2 \%$ with an index value of 137.1 . However, unlike in $2011 \& 2012$, the index growth in 2009 recorded only $2.4 \%$ with an index point recorded of 102.4 . Index growth was at $7.0 \%$ to $12.0 \%$ for 2010,2013 and 2014. As of 2014, the reference to the index and graph growth index almost doubled compared to the base year 2008 with a record 195.9 points.

Table 4: Summary of PSPI Using Laspeyres Hedonic Price Model

\begin{tabular}{|l|c|c|c|c|c|c|c|c|}
\hline \multicolumn{1}{|c|}{ Year } & $\mathbf{2 0 0 8}$ & $\mathbf{2 0 0 9}$ & $\mathbf{2 0 1 0}$ & $\mathbf{2 0 1 1}$ & $\mathbf{2 0 1 2}$ & $\mathbf{2 0 1 3}$ & $\mathbf{2 0 1 4}$ & $\begin{array}{c}\text { Weight } \\
\mathbf{2 0 0 8}\end{array}$ \\
\hline Variables & $\mathbf{B}$ & $\mathbf{B}$ & $\mathbf{B}$ & $\mathbf{B}$ & $\mathbf{B}$ & $\mathbf{B}$ & $\mathbf{B}$ & \\
\hline Intercept & 10.016 & 10.264 & 10.523 & 10.773 & 10.662 & 10.572 & 10.886 & \\
\hline DM154 & 0.747 & 0.814 & 0.821 & 1.148 & 1.111 & 1.182 & 1.060 & 0.254 \\
\hline DP_KEKAL & -0.190 & -0.162 & -0.317 & -0.159 & 0.027 & -0.041 & -0.216 & 0.969 \\
\hline DKK101 & 0.253 & 0.290 & 0.438 & 0.266 & 0.306 & 0.276 & 0.371 & 0.249 \\
\hline DKK103 & 0.112 & 0.119 & 0.224 & 0.097 & 0.106 & 0.111 & 0.179 & 0.508 \\
\hline DKK104 & -0.187 & -0.204 & -0.035 & -0.177 & -0.071 & -0.143 & 0.010 & 0.090 \\
\hline DBH1 & 0.036 & -0.097 & -0.059 & -0.083 & -0.043 & -0.036 & -0.038 & 0.487 \\
\hline D_PREWAR & -0.086 & 0.053 & 0.336 & 0.091 & 0.251 & 0.232 & 0.307 & 0.178 \\
\hline A_TINGKAT & 0.230 & 0.257 & 0.175 & 0.085 & 0.172 & 0.193 & 0.119 & 2.277 \\
\hline A_SYER & 1.737 & 1.553 & 1.606 & 1.641 & 1.459 & 1.575 & 1.603 & 0.937 \\
\hline A_LTNH & 0.002 & 0.003 & 0.002 & 0.002 & 0.003 & 0.003 & 0.003 & 141.636 \\
\hline A_LBGN & 0.001 & 0.000 & 0.001 & 0.001 & 0.000 & 0.000 & 0.001 & 280.765 \\
\hline A_UMUR & -0.003 & -0.009 & -0.011 & -0.013 & -0.011 & -0.011 & -0.011 & 23.782 \\
\hline PM4 & -0.027 & -0.032 & 0.017 & 0.058 & 0.104 & 0.108 & 0.015 & 0.513 \\
\hline PN4 & 0.212 & 0.192 & 0.128 & 0.108 & 0.137 & 0.131 & 0.125 & 0.218 \\
\hline Product & $\mathbf{1 2 . 7 3 1}$ & $\mathbf{1 2 . 7 5 6}$ & $\mathbf{1 2 . 8 6 3}$ & $\mathbf{1 3 . 0 4 7}$ & $\mathbf{1 3 . 2 3 2}$ & $\mathbf{1 3 . 3 0 2}$ & $\mathbf{1 3 . 4 0 4}$ & \\
\hline
\end{tabular}




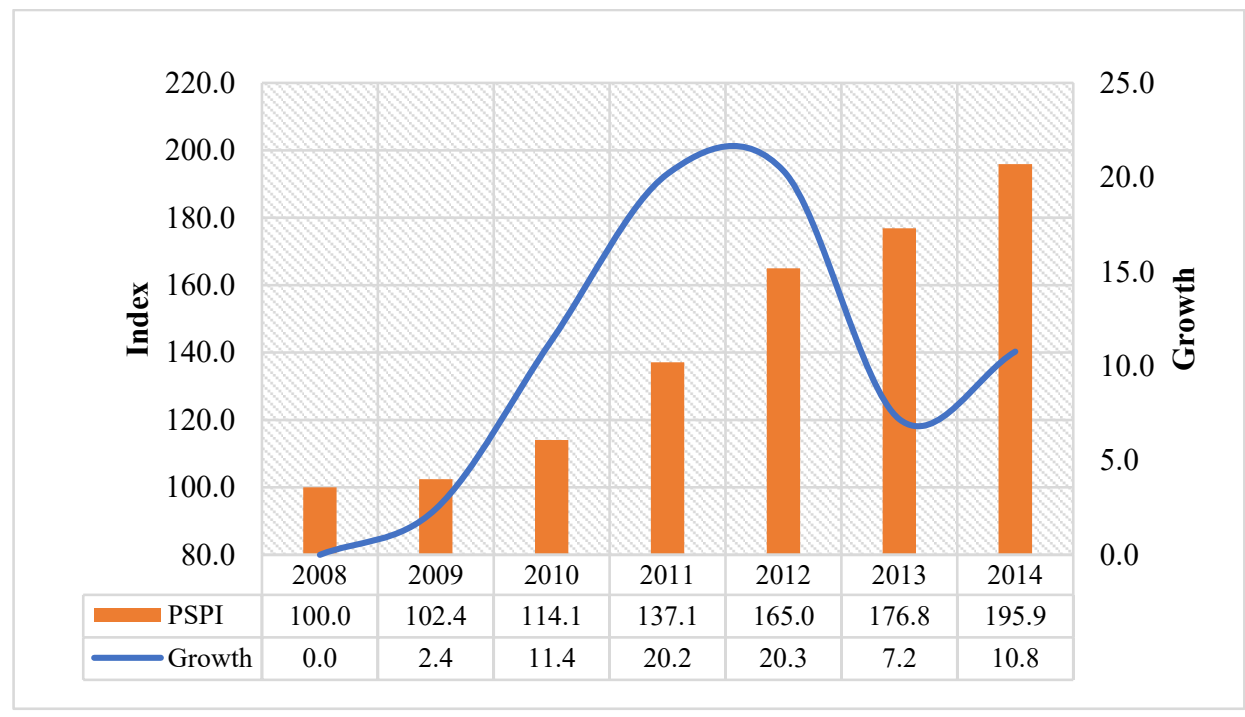

Figure 2: PSPI Index Point and Growth Rate Source: Author

Base on the figure 2, the index growth in 2009 was relatively low compared to the year ahead. This growth may have an impact from the US economy around December 2007 to June 2009 where a subprime crisis happens. According to Sanders (2008), the crisis stems from the overly liberal and loose US credit system in the property sector. The US subprime crisis is not just contagious in the financial markets and economies of major powers with strong trade ties with it such as the United Kingdom, European countries, Japan, and China which have been tempting since 2007 but are also contagious in the financial and economic markets globally as a whole including in Malaysia (Utusan Malaysia, 2008).

\section{DISCUSSION}

Figure 6 below shows a comparison between PSPI and the Penang House Price Index (PHPI) published by NAPIC. Comparisons are made to show the difference in the change rate between these two indices. 
Mohamad Hafiz Jamaludin, Suriatini Ismail, Norziha Ismail

The Development of Penang Shop Price Index (Pspi) Using Laspeyres Hedonic Price Model

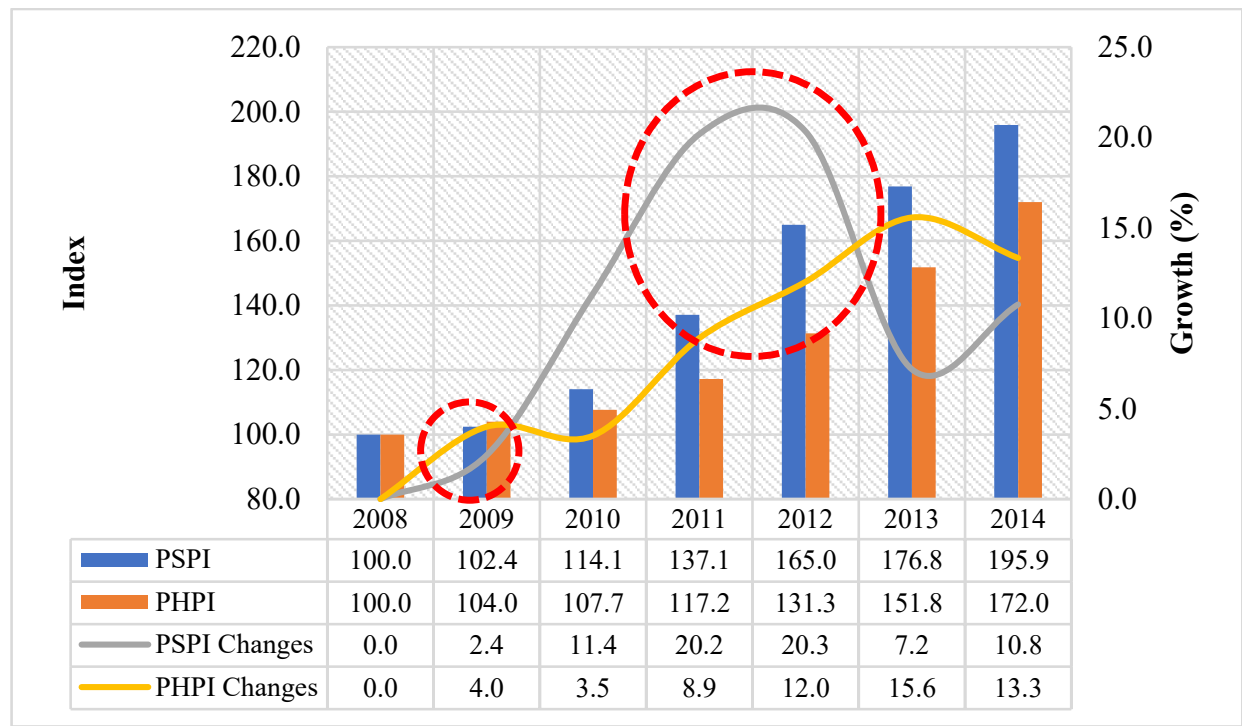

Figure 6: Comparison of Index Point and Growth Between PSPI \& PHPI Source: Author

Overall, the growth recorded by PSPI is higher than PHPI except in 2013 and 2014. This indicates that growth for commercial property is better than residential property. Looking at the growth rate pattern for both indices, the growth rate is quite slow especially in 2009 . Then the peak of growth can be seen starting 2010 and the following years. This indicates that the development of PSPI is in line with the current of the property market.

\section{CONCLUSION}

The existence of property price indicators in Malaysia is still limited. Although various property indicators have been published and disseminated by NAPIC for industry reference, the property market still needs more property price indicators related to commercial property. NAPIC is establish as a data centre, so there is no problem for NAPIC to create more property market indicators with adequate and comprehensive data availability. Therefore, with the development of PSPI, this will not only strengthen the NAPIC entity as an information centre but will also place the country on an equal footing with developed countries in terms of providing property indicators. It is hoped that this study acts as one of the pilot initiatives to develop more commercial property indices and subsequently to develop Malaysian Commercial Property Price Index. 


\section{REFERENCES}

Aina Edayu, A., Md Nasir D. \& Zulkifli E. (2014). Commercial Property Index Construction Methodology: A Review on Literature and Practice. Journal of Design and Built Environment, 14 (2), 1-11.

Aina Edayu, A. (2015). Development of Kuala Lumpur Office Price Index (KL-OPI): An Application of Hedonic Price Model. (Master Thesis) Fakulti Alam Bina, Universiti Malaya.

Bailey, M. J., Muth, R. F., and Nourse, H. O. (1963). A regression method for real estate price index construction. Journal of the American Statistical Association, 58, 933 942 .

Bank Negara Malaysia (BNM) (2009). Buletin Suku Tahunan, Suku Pertama 2009. Diperolehi daripada http://www.bnm.gov.my/ files/publication/qb/2009/Q1/ bm_p3.pdf

Case, K. E. and Shiller, R. J. (1987). Prices of single-family homes since 1970: New indexes for four cities. National Bureau of Economic Research Cambridge, Massachusetts, USA.

Chau, K., Wong, S., Yiu, C. and Leung, H. (2005). Real estate price indices in Hong Kong. Journal of Real Estate Literature, 13, 337-356.

Chegut, A. M., Eichholtz P. M. A. and Rodrigues, P. J. M. (2013). The London commercial property price index. The Journal of Real Estate Finance and Economics, November 2013, 47(4), 588-616.

Farragher, E.J. and Savage, A. (2008). An investigation of real estate investment decisionmaking practices. Journal of Real Estate Practice and Education, 11(1), 29-40.

Fisher, J. D. (2003). US commercial real estate indices: the NCREIF property index. BIS Paper No. 21, 359-367.

Fisher, J. D., Geltner, D. and Pollakowski, H. (2007). A quarterly transactions-based index (TBI) of institutional real estate investment performance and movements in supply and demand. Journal Real Estate Finance and Economics, 34, 5-33.

Francke, M. K. (2010). Repeat Sales Index for Thin Markets. Journal of Real Estate Finance and Economics, July 2010, 41(1), 24-52.

Gatzlaff, D. H. and Haurin, D. R. (1998). Sample selection and biases in local house value indices. Journal of Urban Economics, 43(2), 199-222.

Geltner, D., MacGregor, B. and Schwann, G. (2003). Appraisal smoothing \& price discovery in real estate markets. Urban Studies, 40(5-6), 1047-1064.

Griliches, Z. (1971). Hedonic price indexes of automobiles: an econometric analysis of quality change. Cambridge University Press.

Hasliza, J., Norngainy, M. T., Md Nasir, D. \& Aina Edayu, A. (2018). House Price Movement for Primary and Secondary Markets: Evidence from Selangor, Malaysia. Journal of the Malaysian Institute of Planners, 16(1), 334 - 347.

Haurin, D. R. (2003). US commercial real estate indices: transaction-based and constantliquidity indices. BIS Paper No. 21, 232-242.

IPD Index Guide (2011). Edition Six - January 2011.

Junainah, M. and Suriatini, I. (2019). Capabilities f Revealed Preference Method for Heritage Property Valuation. Journal of the Malaysian Institute of Planners, 17(1), $377-388$

Kementerian Kewangan Malaysia (MOF) (2017). Laporan Ekonomi 2017. 
Mohamad Hafiz Jamaludin, Suriatini Ismail, Norziha Ismail

The Development of Penang Shop Price Index (Pspi) Using Laspeyres Hedonic Price Model

National Council of Real Estate Investment Fiduciaries (NCREIF) (2014). NCREIF Transaction Based Index (TBI) Overview. Obtained from https://www.ncreif.org/data-products/tbi/

National Council of Real Estate Investment Fiduciaries (NCREIF) (2014). Property Index Returns (NPI) Overview. Obtained from https://www.ncreif.org/dataproducts/property/

Pusat Maklumat Harta Tanah Negara (NAPIC) (2012). Laporan Indeks Sewaan Pejabat Binaan Khas Wilayah Persekutuan Kuala Lumpur (WPKL). Jabatan Penilaian dan Perkhidmatan Harta, Kementerian Kewangan Malaysia.

Pusat Maklumat Harta Tanah Negara (NAPIC) (2018). Laporan Indeks Sewaan Pejabat Binaan Khas Lembah Klang, Johor Bahru \& George Town, Suku 1 dan 22018. Jabatan Penilaian dan Perkhidmatan Harta, Kementerian Kewangan Malaysia.

Pusat Maklumat Harta Tanah Negara (NAPIC) (2018). Laporan Indeks Harga Rumah Malaysia, Suku 1 dan 2 2018. Jabatan Penilaian dan Perkhidmatan Harta, Kementerian Kewangan Malaysia.

Pusat Maklumat Harta Tanah Negara (NAPIC) (2014). Laporan Pasaran Harta 2005 2014. Jabatan Penilaian dan Perkhidmatan Harta, Kementerian Kewangan Malaysia.

Quigley, J. M. (1995). A simple hybrid model for estimating real estate price indexes. Journal of Housing Economics, 4, 1-12.

Real Capytal Analytic (RCA) (2014). Moody's/REAL Commercial Property Price Indices (CPPI). Obtained from https://www.rcanalytics.com/our-data/rca_cppi/

Rosen, S. (1974). Hedonic prices and implicit markets: product differentiation in pure competition. The Journal of Political Economy, 82(1), 34-55.

Tuti Haryati, J. (2018). Mediation Effect of Social Aspect in The Relationship Between Environmental and Economic Aspects: Their Influence on The Value of Green Commercial Office Property. Journal of the Malaysian Institute of Planners, $16(1), 251-264$

Received: $12^{\text {th }}$ July 2021. Accepted: $23^{\text {rd }}$ Sept 2021 